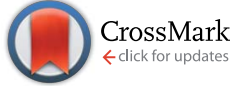

Cite this: RSC Adv., 2017, 7, 7060
Received 30th November 2016 Accepted 26th December 2016

DOI: 10.1039/c6ra27589c

www.rsc.org/advances

\section{Mechanism of palladium(II) biosorption by Providencia vermicola}

\author{
Ling Tan, ${ }^{a}$ Haigang Dong, ${ }^{b}$ Xinxing Liu, ${ }^{a}$ Jia He, ${ }^{a} \mathrm{Hang} \mathrm{Xu}^{\mathrm{a}}$ and Jianping $\mathrm{Xie}^{\star a}$
}

The mechanism of biosorption of $\mathrm{Pd}(\Perp)$ from aqueous solution onto Providencia vermicola biomass was elucidated from the aspects of the biosorption process, multi-scale visualization and functional groups for the first time. Kinetic, equilibrium and thermodynamic experiments revealed that the biosorption process was spontaneous, endothermic and limited by chemical reaction. The multi-scale visualization was conducted by using scanning electron microscopy coupled to energy dispersive $\mathrm{X}$-ray spectroscopy (SEM-EDX), transmission electron microscopy coupled to energy dispersive $X$-ray spectroscopy (TEMEDX) and atomic force microscopy (AFM). It was demonstrated that palladium ions were transformed to both the external and internal of $P$. vermicola biomass, and the morphological properties changed considerably in the nanometer range. The functional groups related to $\mathrm{Pd}\left({ }_{\mathrm{I}}\right)$ binding on the cell wall of $P$. vermicola were confirmed by chemical modification and characterized by Fourier transform infrared spectroscopy (FTIR) and X-ray photoelectron spectroscopy (XPS). The results showed that zero-valent palladium ions were detected in the surface of the biomass, and the most efficient functional groups were carboxylic and hydroxyl groups, followed by phosphate and amine groups.

\section{Introduction}

Palladium is commonly used in catalytic converters of automobiles to lower emissions of harmful pollutants, as well as in refining, electronics, dentistry, and catalysis. ${ }^{1}$ The ability of palladium to catalyze a wide spectrum of reactions in chemical synthesis led the price of palladium to a parallel increase. ${ }^{2}$ In general, mineral ores for the extraction of palladium contain less than $10 \mathrm{~g} \mathrm{t}^{-1}$ whereas the printed circuit boards (PCBs) of personal computers and mobile phones contain $110 \mathrm{~g} \mathrm{t}^{-1}$ and $280 \mathrm{~g} \mathrm{t}^{-1}$ of palladium, respectively. It was reported that palladium made up around $50 \%$ of the economic value of the bare waste computer PCBs after the components were disassembled. $^{3}$ To date, hydrometallurgical processes, which include cementation, solvent extraction, ion exchange, adsorption and precipitation, account for most of the recovery of palladium from scrap. However, the recovery methods generated large quantities of secondary waste since various chemicals were used in the processes. ${ }^{\mathbf{4} 5}$ Hence, it is essential to develop a low-cost, eco-friendly and little secondary wastes generated system, to recover precious metals from wastewater.

In recent years, as an alternative treatment, biosorption process has become an economic and eco-friendly technology in water and wastewater industry. ${ }^{6}$ Many biomaterials, such as

${ }^{a}$ School of Minerals Processing and Bioengineering, Central South University, Changsha 410083, China. E-mail: Xiejianping@csu.edu.cn; Fax: +86-073188836943; Tel: +86-0731-88836943

${ }^{b}$ State Key Laboratory of Advanced Technologies for Comprehensive Utilization of Platinum Metals, Kunming Institute of Precious Metals, Kunming 650106, China bacteria, fungal, marine algae and waste activated sludge, have been investigated as biosorbents to separate and concentrate metals from wastewaters., ${ }^{7,8}$ For example, Yan and Viraraghavan $^{9}$ reported that fungi such as Aspergillus niger and Mucor rouxii were capable of removing heavy metals from aqueous solutions. Chojnacka et al. ${ }^{\mathbf{1 0}}$ investigated the processes of biosorption of heavy metal ions $\left(\mathrm{Cr}^{3+}, \mathrm{Cd}^{2+}, \mathrm{Cu}^{2+}\right)$ by blue-green algae and found that Spirulina sp. was a very efficient biosorbent. Some industrial waste biomass, such as Escherichia coli $^{2,11}$ and Corynebacterium glutamicum, ${ }^{5}$ were also used to recover precious metals like palladium and platinum from aqueous solution. However, the mechanism and characteristics of biosorption of various metals are bacteria dependent since the cell wall are not identical.

Providencia spp., which was used in lead, aluminium, cobalt and copper biosorption, ${ }^{12,13}$ yet, have not been studied for palladium biosorption. The exact process of the metal uptake process, multi-scale visualization of biomass and behavior of the functional groups in the biosorption of palladium are still not clear. The objective of the present work was to investigate the biosorption processes and functional groups of $P$. vermicola biomass for recovering $\mathrm{Pd}(\mathrm{II})$ from aqueous solution. To be specific, the kinetics, equilibrium and thermodynamics characteristics of $\mathrm{Pd}(\mathrm{II})$ biosorption onto P. vermicola were investigated by using model fitting. Furthermore, the multi-scale visualization of blank and palladium-loaded $P$. vermicola biomass were observed using SEM-EDX, TEM-EDX and AFM. Later on, the functional groups and possible binding atoms on the cell wall were characterized by FTIR and XPS analyses. The 
Providencia vermicola biomass was chemically modified to confirm the effects of carboxyl, amine, hydroxyl, phosphate groups on the cell wall.

\section{Materials and methods}

\subsection{Materials}

Providencia vermicola was isolated from soil samples collected from YueLu Mountain (N/E: $28^{\circ} 10.409^{\prime} / 112^{\circ} 54.418^{\prime}$, Changsha, China), and the accession number of $16 \mathrm{~S}$ ribosomal RNA gene is KX394623. The stain was grown aerobically in Luria-Bertani (LB) medium at $30{ }^{\circ} \mathrm{C}$ (under $170 \mathrm{rpm}$ ) for $24 \mathrm{~h}$ with $1 \%$ inoculation, then the $P$. vermicola cells were harvested by centrifugation at $10000 \mathrm{rpm}$ for $15 \mathrm{~min}$, re-suspended in deionized water, and repelleted by centrifugation. This procedure was repeated twice, and the wet biomass was immediately used for Pd(II) biosorption.

Stock solutions of $\mathrm{Pd}(\mathrm{II})$ were prepared by dissolving $\mathrm{PdCl}_{2}$ (99.0\%) into $0.1 \mathrm{M} \mathrm{HCl}$, to obtain a concentration of $500 \mathrm{mg} \mathrm{L}^{-1}$, which were diluted as necessary.

\subsection{Biosorption experiments}

The biosorption experiments were carried out by contacting $0.4 \mathrm{~g}$ of wet biomass (equivalent to $0.075 \mathrm{~g}$ of dry biomass) with $50 \mathrm{~mL}$ of palladium solution, with an initial concentration of $200 \mathrm{mg} \mathrm{L}^{-1}$ at different $\mathrm{pH}$ values. The suspension was agitated at $170 \mathrm{rpm}$ in a shaker at $30 \pm 1{ }^{\circ} \mathrm{C}$. After $4 \mathrm{~h}$ of shaking, which was sufficient to attain equilibrium, the samples were harvested and centrifuged to obtain solid-liquid separation. The $\operatorname{Pd}(\mathrm{II})$ concentration remaining in the supernatant were analyzed using an inductively coupled plasma (ICP) spectrometer (Shimadzu, ICP-7510, Japan).

Biosorption kinetic experiments were conducted using the same method as above, except that the $\mathrm{pH}$ was set at 2.0, 3.0 and 4.0 and the samples were collected at different time intervals to determine the time point at which biosorption equilibrium was attained sufficiently.

Biosorption equilibrium experiments were carried out by contacting $0.4 \mathrm{~g}$ of wet biomass with $50 \mathrm{~mL}$ of Pd(II) solution at temperatures of $293,303,313$, and $323 \mathrm{~K}$, respectively. The initial Pd(II) concentration was varied from 100 to $400 \mathrm{mg} \mathrm{L}^{-1}$ and $\mathrm{pH}$ was maintained at 4.0. After the system reached the equilibrium state, the samples were taken to determine the concentration of $\operatorname{Pd}(\mathrm{II})$.

Adsorption capacity was calculated according to the eqn (1):

$$
q_{\mathrm{t}}=\frac{\left(c_{0}-c\right) v}{m}
$$

where $q_{\mathrm{t}}\left(\mathrm{mg} \mathrm{g}^{-1}\right)$ is the adsorption capacity of biomass, $v(\mathrm{~L})$ indicates the volume of samples, $C_{0}$ and $C\left(\mathrm{mg} \mathrm{L}^{-1}\right)$ are the initial and final concentrations of metal ions in the solution, and $m(\mathrm{~g})$ is the dry weight of biosorbent.

\subsection{Chemical modification experiments}

Portions of blank $P$. vermicola biomass were chemically treated in different ways, and then $0.4 \mathrm{~g}$ wet blank and modified biomass were used for biosorption using the same methods as described. After biosorption, portion of the biomass was freezedried for analytical purpose.

The chemical treatment applied to the biomass were as follows:

Blank P. vermicola: conditioned biomass without modification were labeled as 'a'.

Esterification of the carboxylic groups: $5 \mathrm{~g}$ wet biomass was suspended in $65 \mathrm{~mL}$ of anhydrous methanol, and $0.6 \mathrm{~mL}$ of concentrated hydrochloric acid was added to the suspension. The reaction mixture was shaken on a rotary shaker for $6 \mathrm{~h}$ at $170 \mathrm{rpm}$. It has been shown that this treatment caused esterification of the carboxylic acids present on Aspergillus niger ${ }^{14}$ The resulted biomass samples were labeled as ' $b$ '. The reaction occurs as follow:

$$
\mathrm{RCOOH}+\mathrm{CH}_{3} \mathrm{OH}^{\mathrm{H}^{+}} \rightarrow \mathrm{RCOOCH}_{3}+\mathrm{H}_{2} \mathrm{O}
$$

Methylation of the amines: $5 \mathrm{~g}$ wet biomass was contacted with $40 \mathrm{~mL}$ of formic acid and $20 \mathrm{~mL}$ of formaldehyde. The reaction mixture was shaken on an agitator at $170 \mathrm{rpm}$ for $6 \mathrm{~h}$. This treatment was expected to result in the methylation of amines. ${ }^{15}$ The resulted biomass samples were labeled as ' $c$ '. The general reaction occurs as follow:

$$
\mathrm{RCH}_{2} \mathrm{NH}_{2} \stackrel{\text { HCHO,HCOOH }}{\longrightarrow} \mathrm{RCH}_{2} \mathrm{~N}\left(\mathrm{CH}_{3}\right)_{2}+\mathrm{CO}_{2}+\mathrm{H}_{2} \mathrm{O}
$$

Esterification of the hydroxyl groups: $5 \mathrm{~g}$ of raw biomass was suspended in $30 \mathrm{~mL}$ mixture of pyridine and acetic anhydride (12 to 88 volume ratio) and heated for $2 \mathrm{~h}$ at $60^{\circ} \mathrm{C}$. The treatment was widely applied for determination of hydroxyl content of carboxylic acids. ${ }^{16}$ The biomass samples obtained were labeled as ' $\mathrm{d}$ '. The reaction occurs as follows:

$$
\mathrm{RCH}_{2} \mathrm{NH}_{2}+\left(\mathrm{CH}_{3} \mathrm{CO}\right)_{2} \mathrm{O} \rightarrow \mathrm{RCH}_{2} \mathrm{NHCOCH}_{3}+\mathrm{CH}_{3} \mathrm{COOH}
$$

$$
\mathrm{RCH}_{2} \mathrm{OH}+\left(\mathrm{CH}_{3} \mathrm{CO}\right)_{2} \mathrm{O} \rightarrow \mathrm{RCH}_{2} \mathrm{OCOCH}_{3}+\mathrm{CH}_{3} \mathrm{COOH}(
$$

Esterification of the phosphate groups: $5 \mathrm{~g}$ wet biomass was heated under reflux conditions with $40 \mathrm{~mL}$ of triethyl phosphite and $30 \mathrm{~mL}$ of nitromethane for $6 \mathrm{~h}$. Tobin et al.(1990) reported that this treatment causes esterification of the phosphate groups which may be present on the biomass. ${ }^{17}$ The resulted biomass samples were labeled as ' $\mathrm{e}$ '. The reaction occurs as follow:

$$
\begin{aligned}
3 \mathrm{RCH}_{2} \mathrm{PO}_{4} \mathrm{H}+\left(\mathrm{CH}_{3} \mathrm{CH}_{2} \mathrm{O}\right)_{3} \mathrm{P}_{3} \stackrel{\mathrm{CH}_{3} \mathrm{NO}_{2}}{\longrightarrow} & 3 \mathrm{RCH}_{2} \mathrm{PO}_{4} \mathrm{CH}_{2} \mathrm{CH}_{3}+\mathrm{H}_{3} \mathrm{PO}_{4}
\end{aligned}
$$

Extraction of the lipid fraction: $5 \mathrm{~g}$ of wet biomass was heated under reflux with $50 \mathrm{~mL}$ of acetone for $2.5 \mathrm{~h} .{ }^{17}$ The resulted biomass samples were labeled as ' $\mathrm{f}$ '.

\subsection{Analytical methods}

The samples before and after biosorption were freeze-dried for Scanning Electron Microscopy (SEM) analyses. SEM-EDX 
analysis was performed on an environmental SEM (Quanta-200, FEI, UK) at $10 \mathrm{kV}$ accelerating voltage. Transmission Electron Microscopy (TEM) analysis was carried out using a Tecnai G2 20 ST equipped with an energy dispersive X-ray (EDX) attachment. Prior to analysis, ultrathin sections of blank and palladiumloaded samples were cut using an ultramicrotome and then mounted on a copper TEM grid. Samples for Atomic Force Microscopy (DI Multimode V, VEECO, USA) analysis were airdried in mica sheets overnight, and operated in tapping mode at a scan rate of $1.0 \mathrm{~Hz}$ using RTESP probes. For FTIR analysis, $50 \mathrm{mg}$ of $\mathrm{KBr}$ disks containing $2 \%$ of freeze-dried powder of the each sample were prepared and then examined using a Nicolet 6700 FTIR spectrophotometer (USA). The spectra were recorded in the region of $4000-625 \mathrm{~cm}^{-1}$ at the resolution of $4 \mathrm{~cm}^{-1}$ with 32 scans. X-ray photoelectron spectroscopy (XPS) was conducted by Thermo Scientific ESCALAB 250Xi (UK) equipped with an electron flood gun and a scanning ion gun, using the $\mathrm{Al} \mathrm{K} \alpha$ radiation $(1486.6 \mathrm{eV})$ as the excitation source. The binding energy scale was calibrated with respect to adventitious carbon (C 1s).

\section{Results and discussion}

\subsection{Study on biosorption process}

3.1.1 Biosorption kinetics. Lagergren's pseudo-first-order equation, and the pseudo-second-order equation were tested to fit the experimental data (Fig. 1a). The mathematical representations of the two models are given in eqn (7) and (8), respectively.

$$
\begin{gathered}
\ln \left(q_{\mathrm{e}}-q_{t}\right)=\ln q_{\mathrm{e}}-k_{1} t \\
\frac{t}{q_{t}}=\frac{1}{k_{2} q_{\mathrm{e}}^{2}}+\frac{t}{q_{\mathrm{e}}}
\end{gathered}
$$

where both $q_{\mathrm{e}}$ is the amount of solute sorbed at equilibrium (mg $\left.\mathrm{g}^{-1}\right), q_{t}$ is the amount of solute sorbed at any time $t\left(\mathrm{mg} \mathrm{g}^{-1}\right), k_{1}$ is the pseudo-first-order rate constant $\left(\mathrm{L} \mathrm{min}^{-1}\right)$ and $k_{2}$ is the pseudo-second-order rate constant $\left(\mathrm{g}\left(\mathrm{mg}^{-1} \mathrm{~min}^{-1}\right)\right)$. The experimental and predicted equilibrium uptakes, rate constants, and corresponding correlation coefficient are summarized in Table 1.

As shown in Fig. 1a, the biosorption capacity of $P$. vermicola was significantly influenced by solution $\mathrm{pH}$ with the sorption capacity of 93.04 (pH 2.0), 107.15 (pH 3.0) and $115.79(\mathrm{pH} 4.0)$ respectively. And the $\mathrm{Pd}(\mathrm{II})$ biosorption was a rapid process, the adsorption reached equilibrium when the biomass contacted with Pd(II) for $180 \mathrm{~min}$. The kinetic curve for Pd(II) showed rapid biosorption during the first $10 \mathrm{~min}$ at $\mathrm{pH}$ 4, with a $\mathrm{Pd}(\mathrm{II})$ removal efficiency of $80 \%$.

The correlation coefficients in the pseudo-first-order model were in the range of $0.70-0.76$ (Table 1 ), but the calculated $q_{\mathrm{e}}$ were not consistent with the experimental $q_{\mathrm{e}}$ values, since the pseudo-first-order model only represented kinetic experiment data of the rapid initial phase. ${ }^{2}$ Conversely, the pseudo-secondorder model, based on the assumption that the rate-limiting step may be chemical sorption involving valency forces through sharing or exchange of electrons between sorbent and sorbate, provided the best correlation of the data. ${ }^{18,19}$ On the other hand, the rate constant calculated from both pseudo-firstorder $\left(k_{1}\right)$ and pseudo-second-order $\left(k_{2}\right)$ at pH 2.0 and 3.0 were only $0.285,0.005$ and $0.256,0.004$, much lower than 0.384 and 0.006 at $\mathrm{pH} 4.0$, which meant that the adsorption process was significantly hindered under low $\mathrm{pH}$.

In contrast to pseudo-second-order model, the intraparticle diffusion model (eqn (9)) may provide a more comprehensive view of adsorption.

$$
q_{t}=k_{\mathrm{i}} t^{0.5}+C
$$

where $k_{\mathrm{i}}$ is the intraparticle diffusion rate constant $\left(\mathrm{mg} \mathrm{g}^{-1}\right.$ $\min ^{-0.5}$ ), which can be calculated from the slop of the linear plots of $q_{t}$ versus $t^{0.5}$.

According to Weber and Morris, if the rate-limiting step is intraparticle diffusion, a plot of solute sorbed against the square root of the contact time should yield a straight line passing through the origin. ${ }^{20}$ If the plot shows multi-linearity, it indicates that further complexity exists in the adsorption process. ${ }^{21}$ Multi-linearity was clearly observed over the whole time range as shown in Fig. 1b, indicating that two steps
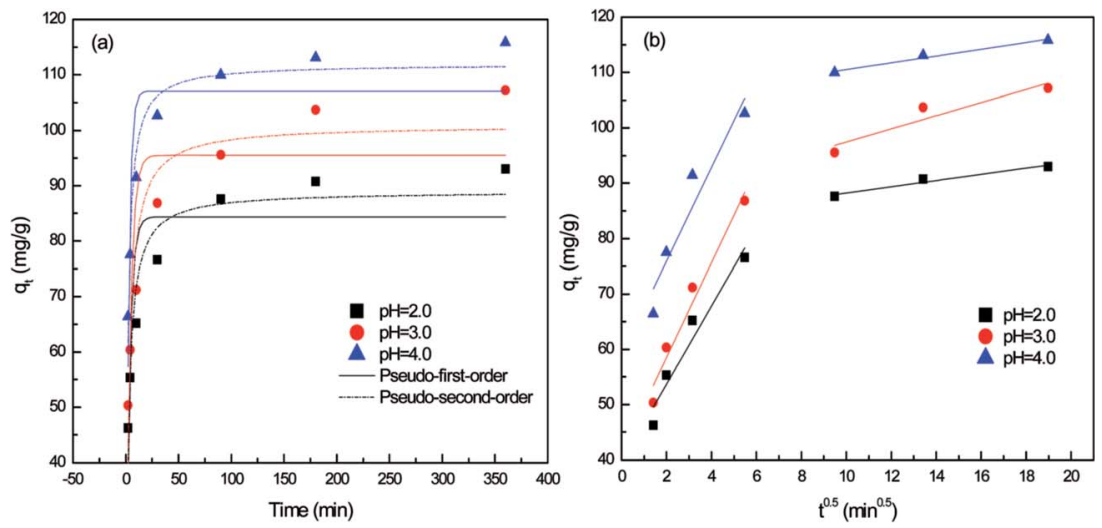

Fig. 1 Non-linear kinetic fits of for P. vermicola biomass at different pH. (a) Pseudo-first-order and pseudo-second-order model; (b) intraparticle diffusion model. 
Table 1 Kinetic parameters of pseudo-first-order, pseudo-second-order model and intraparticle diffusion model for $P$. vermicola biomass at different $\mathrm{pH}$

\begin{tabular}{|c|c|c|c|c|c|}
\hline Fitting models & Stages & Parameters & $\mathrm{pH}=2.0$ & $\mathrm{pH}=3.0$ & $\mathrm{pH}=4.0$ \\
\hline \multirow[t]{3}{*}{ Pseudo-first-order model } & & Experimental $q_{\mathrm{e}}\left(\mathrm{mg} \mathrm{g}^{-1}\right)$ & 93.038 & 107.734 & 115.791 \\
\hline & & Predicted $q_{\mathrm{e}}\left(\mathrm{mg} \mathrm{g}^{-1}\right)$ & 84.332 & 95.493 & 107.059 \\
\hline & & $R^{2}$ & 0.713 & 0.706 & 0.755 \\
\hline \multirow[t]{2}{*}{ Pseudo-second-order model } & & Predicted $q_{\mathrm{e}}\left(\mathrm{mg} \mathrm{g}^{-1}\right)$ & 89.000 & 100.929 & 111.934 \\
\hline & & $K_{2}\left(\mathrm{~g} \mathrm{mg}^{-1} \min ^{-1}\right)$ & 0.005 & 0.004 & 0.006 \\
\hline & & $K_{\mathrm{i} 1}\left(\mathrm{mg} \mathrm{g}^{-1} \min ^{-0.5}\right)$ & 7.068 & 8.569 & 8.456 \\
\hline & & $R^{2}$ & 0.918 & 0.953 & 0.875 \\
\hline & Second stage & $C\left(\mathrm{mg} \mathrm{g}^{-1}\right)$ & 82.579 & 85.637 & 104.421 \\
\hline & & $K_{\mathrm{i} 2}\left(\mathrm{mg} \mathrm{g}^{-1} \min ^{-0.5}\right)$ & 0.564 & 1.183 & 0.609 \\
\hline & & $R^{2}$ & 0.928 & 0.788 & 0.962 \\
\hline
\end{tabular}

governed adsorption rather than one. The first sharper stage was film physical diffusion, in which Pd(II) were transported onto the external surface of biomass. The second stage described the gradual biosorption, where metals were sorbed on the interior of the biomass and intraparticle diffusion was rate-limiting. As reflected in Table 1, the intraparticle diffusion rate constant in first stage was higher than that in later stage $\left(k_{\mathrm{i} 1}\right.$ $>k_{\mathrm{i} 2}$ ), which were observed in $\mathrm{pH}$ 2.0, 3.0 and 4.0. It meant that the exterior surface adsorption was an instantaneous diffusion process. When exterior surface reached saturation, palladium ions entered the biomass on the second stage with increased diffusion resistance, resulting in a decrease of diffusion rates $\left(k_{\mathrm{i} 2}\right)$. As $\operatorname{Min}^{22,23}$ reported, the adsorption was controlled by two steps or more, including boundary layer or external diffusion, pore diffusion, surface diffusion and adsorption onto the pore surface, or a combination of several steps, of which the intraparticle diffusion step was the most rate-limiting procedure. The multi-linearity in the shape of the intraparticle diffusion plot had also been observed by Ofomaja in the biosorption of lead, methylene blue and methyl violet onto mansonia wood sawdust. ${ }^{21,24}$

3.1.2 Biosorption equilibrium. The biosorption isotherm models describe the correlation between the mass of solute sorbed per unit mass of sorbent at equilibrium. The biosorption isotherms were calculated using two different isotherms models including the Langmuir, and Freundlich isotherms (Fig. 2).

The saturated monolayer isotherm model can be represented as Langmuir, and the mathematical representation is given in eqn (10).

$$
q_{\mathrm{e}}=\frac{q_{\mathrm{m}} K_{\mathrm{L}} C_{\mathrm{e}}}{1+K_{\mathrm{L}} C_{\mathrm{e}}}
$$

where $q_{\mathrm{e}}$ is the amount of metal ion sorbed $\left(\mathrm{mg} \mathrm{g}^{-1}\right) ; q_{\mathrm{m}}$ is the saturated sorption capacity $\left(\mathrm{mg} \mathrm{g}^{-1}\right) ; K_{\mathrm{L}}$ is biosorption equilibrium constant $\left(\mathrm{L} \mathrm{mg}^{-1}\right)$ and $C_{\mathrm{e}}$ is the equilibrium concentration $\left(\mathrm{mg} \mathrm{L}^{-1}\right)$ remained in the solution.

The empirical Freundlich isotherm model, based on sorption on heterogeneous surface, is given by eqn (11).

$$
q_{\mathrm{e}}=K_{\mathrm{F}} C_{\mathrm{e}}^{1 / n}
$$

where $q_{\mathrm{e}}$ is the amount of metal ion sorbed $\left(\mathrm{mg} \mathrm{g}^{-1}\right) ; C_{\mathrm{e}}$ is the equilibrium concentration $\left(\mathrm{mg} \mathrm{L}^{-1}\right)$ remained in the solution; $K_{\mathrm{F}}$ and $1 / n$ are the Freundlich constants characteristics of the system, indicating the sorption capacity and sorption intensity, respectively; and $n$ is the heterogeneity factor which is also known as Freundlich coefficient.

In present study, correlation coefficients $\left(R^{2}\right)$ showed that the Langmuir model fitted the Pd(II) biosorption data better than the Freundlich model, implying a monolayer adsorption trend. ${ }^{25}$ The isotherm data calculated from Freundlich isotherm (Table 2) revealed that the $1 / n$ values for $\operatorname{Pd}(\mathrm{II})$ at 293 , 303,313 and $323 \mathrm{~K}$ were $0.281,0.268,0.278$ and 0.307 , respectively. The value of $1 / n$ range between 0 and 1 further confirmed the favorable adsorption for palladium ions. Furthermore, the isotherms with $n$ values greater than unity were classified as L-type isotherms which showed that there was high affinity between adsorbate and adsorbent surface..$^{23,26}$ The maximum biosorption capacity calculated from Langmuir isotherm presented in Table 2 was $196.806 \mathrm{mg} \mathrm{g}^{-1}$ for the biosorption of $\mathrm{Pd}(\mathrm{II})$. This biosorption capacity is higher than

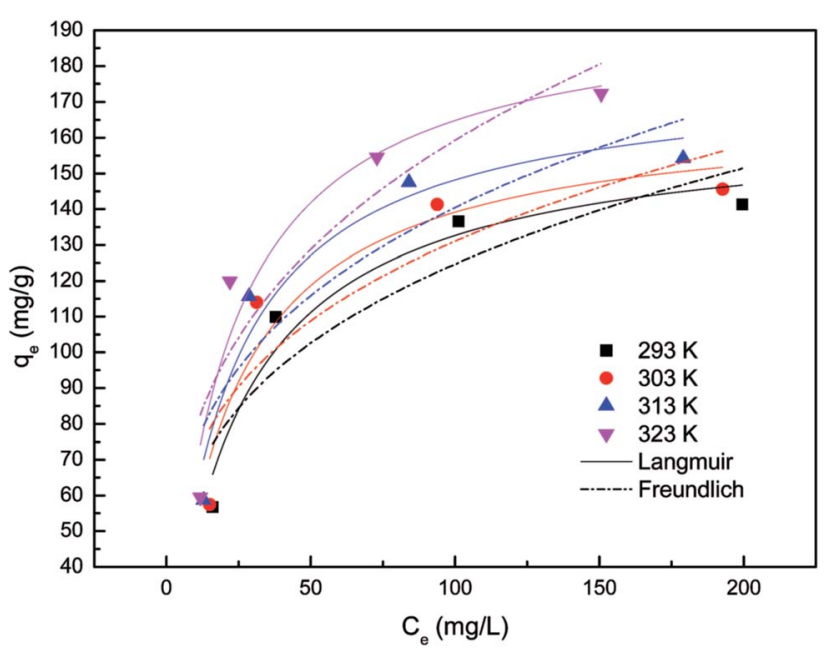

Fig. 2 Non-linear fits of Langmuir and Freundlich isotherm models for $P$. vermicola biomass. 
Table 2 Isothermic parameters of Langmuir and Freundlich models for $P$. vermicola biomass

\begin{tabular}{|c|c|c|c|c|}
\hline \multirow[b]{2}{*}{ Isotherm } & \multicolumn{4}{|l|}{$T(\mathrm{~K})$} \\
\hline & 293 & 303 & 313 & 323 \\
\hline \multicolumn{5}{|l|}{ Langmuir } \\
\hline$q_{\mathrm{m}}\left(\mathrm{mg} \mathrm{g}^{-1}\right)$ & 164.313 & 168.101 & 177.659 & 196.806 \\
\hline$K_{\mathrm{L}}\left(\mathrm{L} \mathrm{mg}^{-1}\right)$ & 0.042 & 0.048 & 0.050 & 0.052 \\
\hline$r^{2}$ & 0.930 & 0.882 & 0.923 & 0.907 \\
\hline \multicolumn{5}{|l|}{ Freundlich } \\
\hline $1 / n$ & 0.281 & 0.268 & 0.278 & 0.307 \\
\hline$K_{\mathrm{F}}\left(\mathrm{mg} \mathrm{g}^{-1}\right)\left(\mathrm{L} \mathrm{mg}^{-1}\right)^{1 / n}$ & 34.144 & 38.142 & 39.073 & 38.791 \\
\hline$r^{2}$ & 0.743 & 0.681 & 0.734 & 0.779 \\
\hline
\end{tabular}

those reported for Racomitrium lanuginosum ${ }^{27}$ and Escherichia coli. $^{28}$

3.1.3 Biosorption thermodynamics. Thermodynamic considerations of a biosorption process are necessary to conclude whether the process is spontaneous or not. The Gibbs free energy $\left(\Delta G^{0}\right)$ change, is an indication of spontaneity of a chemical reaction and therefore is an important criterion for spontaneity. Also, both enthalpy $\left(\Delta H^{0}\right)$ and entropy $\left(\Delta S^{0}\right)$ factors must be considered to determine the Gibbs free energy of the process. These parameters were calculated according to following equations.

$$
\begin{gathered}
\Delta G^{0}=-R T \ln K_{\mathrm{L}} \\
\Delta G^{0}=\Delta H^{0}-T \Delta S^{0}
\end{gathered}
$$

where $\Delta G^{0}$ is the standard Gibbs free energy change (J), $R$ the universal gas constant, $8.314 \mathrm{~J} \mathrm{~mol}^{-1} \mathrm{~K}^{-1}, T$ is absolute temperature $(\mathrm{K}), K_{\mathrm{L}}$ is the equilibrium constant of Langmuir, $\Delta H^{0}$ is the enthalpy change, and $\Delta S^{0}$ is the entropy change.

The Gibbs free energy change $\left(\Delta G^{0}\right)$ and temperature $(T)$ showed a linear relationship (Fig. 3). The values of $\Delta H^{0}$ and $\Delta S^{0}$ were determined from the slope and intercept of the plot. Gibbs

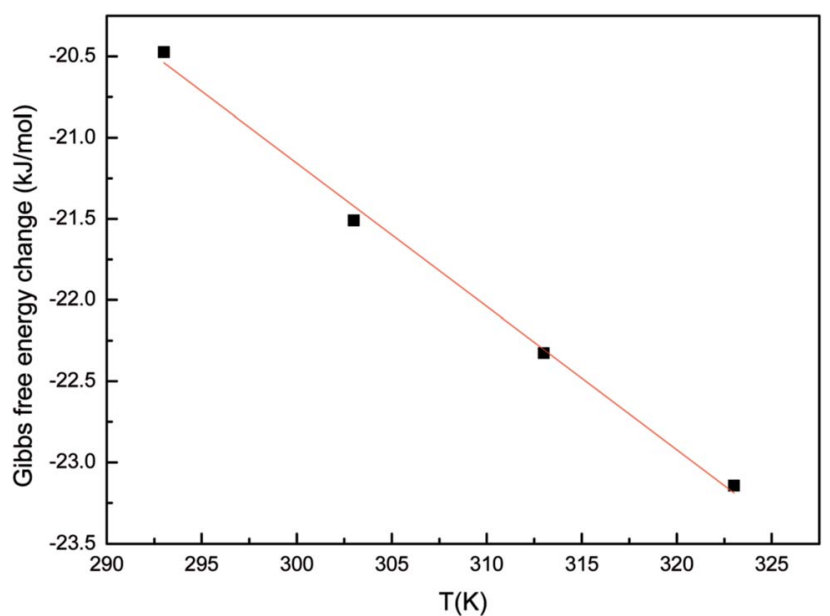

Fig. 3 Plot of $\Delta G^{0}$ vs. $T$ for the estimation of thermodynamic parameters for $P$. vermicola biomass. free energy change $\left(\Delta G^{0}\right)$ were $-20.47,-21.51,-22.33,-23.14$ $\mathrm{kJ} \mathrm{mol}^{-1}$ for $\mathrm{Pd}(\mathrm{II})$ biosorption at 293, 303, 313 and $323 \mathrm{~K}$, respectively. The enthalpy change $\left(\Delta H^{0}\right)$ and the entropy change $\left(\Delta S^{0}\right)$ for the biosorption process were $5.319 \mathrm{~kJ} \mathrm{~mol}^{-1}$ and 0.088 $\mathrm{J} \mathrm{mol}^{-1} \mathrm{~K}^{-1}$, respectively. Negative values of $\Delta G^{0}$ confirmed the feasibility of the process and the spontaneous nature of biosorption with a high preference for palladium on $P$. vermicola. The value of $\Delta H^{0}$ was positive, indicating that the biosorption reaction was endothermic. In addition, negative enthalpy $\left(\Delta H^{0}\right)$ was characteristic of metal ions coordination with amino and sulfhydryl groups, whereas coordination with oxygenous functional groups resulted in small positive enthalpies. ${ }^{29,30}$ The result implied that the $\mathrm{Pd}(\mathrm{II})$ might be bound to the oxygen atoms from active groups $($ e.g. $-\mathrm{COOH}$ and $-\mathrm{OH})$ on the cell wall in this case. The positive value of $\Delta S^{0}$ reflected the affinity of $P$. vermicola for palladium ions and suggested some structural changes during the biosorption process. Further, positive value of $\Delta S^{0}$ showed increasing randomness at the solid/liquid interface during the biosorption of $\mathrm{Pd}(\mathrm{II})$ onto P. vermicola. ${ }^{25}$ Mehrorang et al. reported that the biosorption of $\mathrm{Co}^{2+}, \mathrm{Cu}^{2+}$, $\mathrm{Ni}^{2+}, \mathrm{Pb}^{2+}$ and $\mathrm{Zn}^{2+}$ ions onto Trichoderma reesei biomass was feasible, spontaneous and endothermic at the optimized conditions. ${ }^{31}$ Also, during the process of removal of $\mathrm{Cd}(\mathrm{II})$ and $\mathrm{Cu}$ (II) from aqueous solution by magnesium chloride-modified Lentinula edodes, the thermodynamic parameters determined indicated that the biosorption process was endothermic and spontaneous. $^{32}$

\subsection{Multi-scale visualization of Providencia vermicola biomass}

3.2.1 SEM-EDX analysis. $P$. vermicola cells (palladiumloaded biomass) were observed using SEM-EDX after exposure to an aqueous $\mathrm{PdCl}_{2}$ solution. Since there was no obvious morphology difference between blank and palladium-loaded biomass (data not shown), the palladium-loaded biomass (Fig. 4a) was subjected to EDX analysis. Fig. 4b showed a representative energy dispersive spectrum of palladiumloaded biomass of $P$. vermicola, specific peaks for palladium and chloride were detected with carbon, nitrogen, oxygen, phosphorus and sulfur. The later elements were derived from the $P$. vermicola cell, whereas palladium and chloride were traces of palladium complexes sorbed on the surface of $P$. vermicola biomass. To further confirm the location of the palladium deposition, the EDX maps of palladium and chloride were obtained (Fig. 4c and d). As a result, palladium and chloride were present all everywhere just like the distribution of $P$. vermicola cells in Fig. 4a, indicating the uniform distribution of palladium complexes on the biomass. Table 3 summarized the surface elemental composition of section 1 of Fig. 4a. It revealed that the wt $\%$ of $\mathrm{Pd}$ and $\mathrm{Cl}$ reached $18.40 \%$ and $4.32 \%$, respectively. Compared to other researches, it was observed from SEM pictures that the surface of the biomass becomes rougher and shows the presence of new shiny bulky particles over the surface of the biomass saturated with $\mathrm{Cr}(\mathrm{vI})$ than in case of before adsorption. ${ }^{33}$ When using Aspergillus niger for removal of chromium(vi), the SEM-EDX analyses revealed that chromium was 

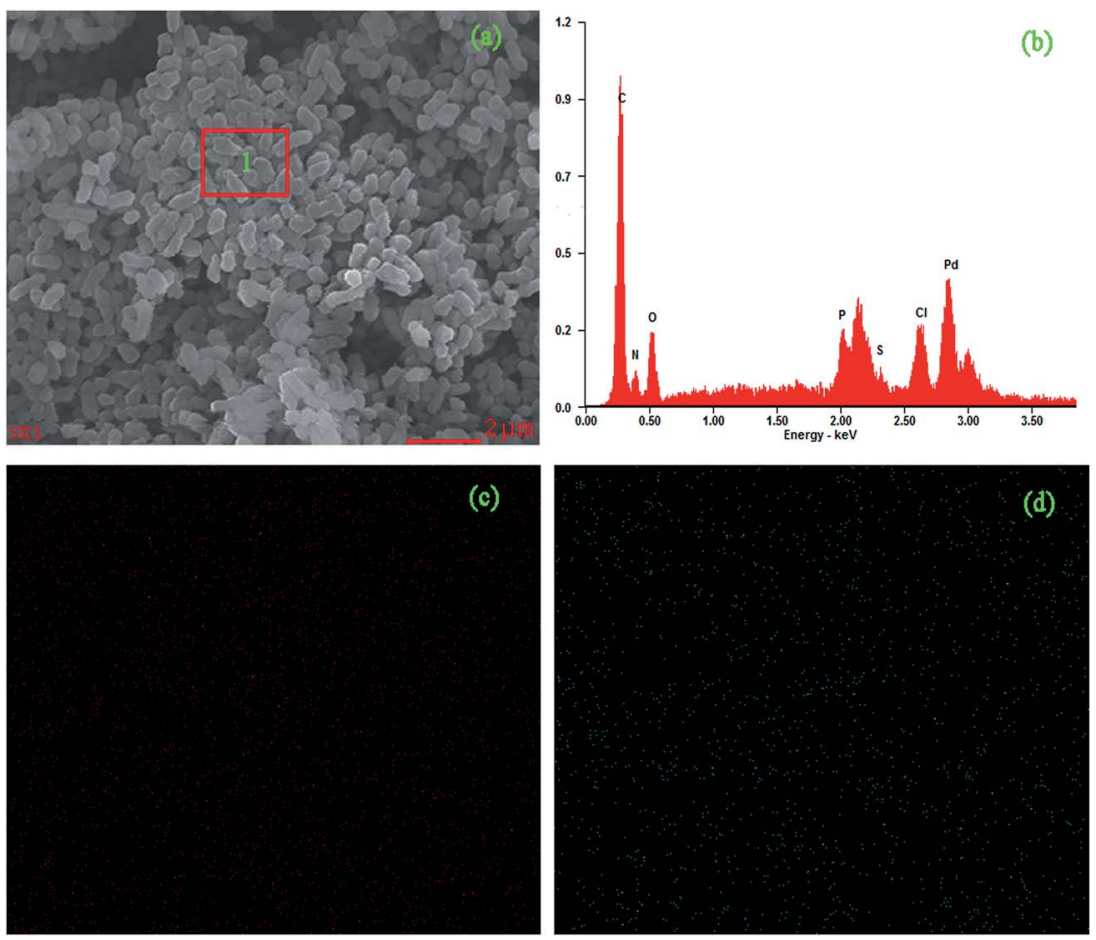

Fig. 4 SEM-EDX analyses of palladium-loaded biomass after exposure to $200 \mathrm{mg} \mathrm{g}^{-1}$ aqueous $\mathrm{PdCl}_{2}$ solution for $3 \mathrm{~h}$. (a) Micrograph of palladium-loaded biomass; (b) spot profile EDX spectrum recorded from region 1; (c) X-ray maps of palladium from '(a)' obtained by EDX analysis; (d) X-ray maps of chloride from '(a)' obtained by EDX analysis.

uniformly bound to the fungal mycelium and a higher chromate absorption together with flocculation in mycelium was observed..$^{34}$

3.2.2 TEM-EDX analysis. TEM-EDX was used to investigate whether palladium ions presented in the internal of cells or not. As shown in Fig. 5a and b, the average dimension of these cells was about $2.0 \mu \mathrm{m}$ long and $0.8 \mu \mathrm{m}$ wide, but the difference between images of blank and palladium-loaded $P$. vermicola was invisible similar to results obtained by SEM. Therefore, samples were analyzed by energy dispersive X-ray (EDX) together with TEM, allowing to verify the presence of palladium in the cells. The EDX spectra derived from blank biomass indicated that it consisted of carbon, oxygen, phosphorus (Fig. 5c). The copper peak was from the grid used to support the sections, and the lead peak originated from the $\mathrm{Pb}\left(\mathrm{CH}_{3} \mathrm{COO}\right)_{2}$ used the cell pellet staining. Furthermore, EDX spectra (Fig. 5d) originating from palladium-loaded biomass exhibited the characteristic peak of

Table 3 Surface elemental composition of palladium-loaded biomass by SEM-EDX analysis

\begin{tabular}{lll}
\hline Element & Wt $\%$ & At $\%$ \\
\hline C & 45.55 & 62.50 \\
$\mathrm{~N}$ & 13.55 & 15.94 \\
$\mathrm{O}$ & 14.14 & 14.56 \\
$\mathrm{P}$ & 02.95 & 01.57 \\
$\mathrm{~S}$ & 01.09 & 00.56 \\
$\mathrm{Cl}$ & 04.32 & 02.01 \\
$\mathrm{Pd}$ & 18.40 & 02.85
\end{tabular}

palladium, which confirmed the presence of palladium ions in the internal of cells. Since the SEM-EDX and TEM-EDX confirmed the existence of palladium ions in both external and internal of $P$. vermicola biomass. The process involving the binding of palladium ions could occur as follows: firstly, the palladium bound to functional groups by electrostatic interaction; it was subsequently transported into the cytoplasm through different layers (peptidoglycan, teichoic acids) of the cell wall and cytoplasmic membrane, and gradually formed complexes. ${ }^{35}$ Likewise, by using HAADF-STEM-EDX analysis, Omajali et $a .^{36}$ proved that intracellular palladium nanoparticles were formed in B. benzeovorans with $\mathrm{H}_{2}$ or formate as electron donors. Koshiro et al. reported that the rhodium nanoparticles were deposited intracellularly in Shewanella algae by comparing the biogenic nanoparticles in the TEM image and the X-ray map for rhodium. ${ }^{37}$

3.2.3 AFM analysis. Visualizing microbial surface at higher resolution, preferably in the nanometer level, is crucial to understand the structure changes after exposing in palladium solution. Although SEM and TEM images showed no big morphological difference between blank and palladium-loaded biomass, AFM results showed that the surface of the palladiumloaded biomass was clearly different from that of the blank biomass (Fig. 6). The blank P. vermicola seemed to huddle together with clear boundaries between each other (Fig. 6a), and the phase image showed some wrinkles (Fig. 6b) which might because of the extrusion force. In addition, their surface had a relative smooth appearance and preserved the integrity of cell structure including the shape and size. However, the 


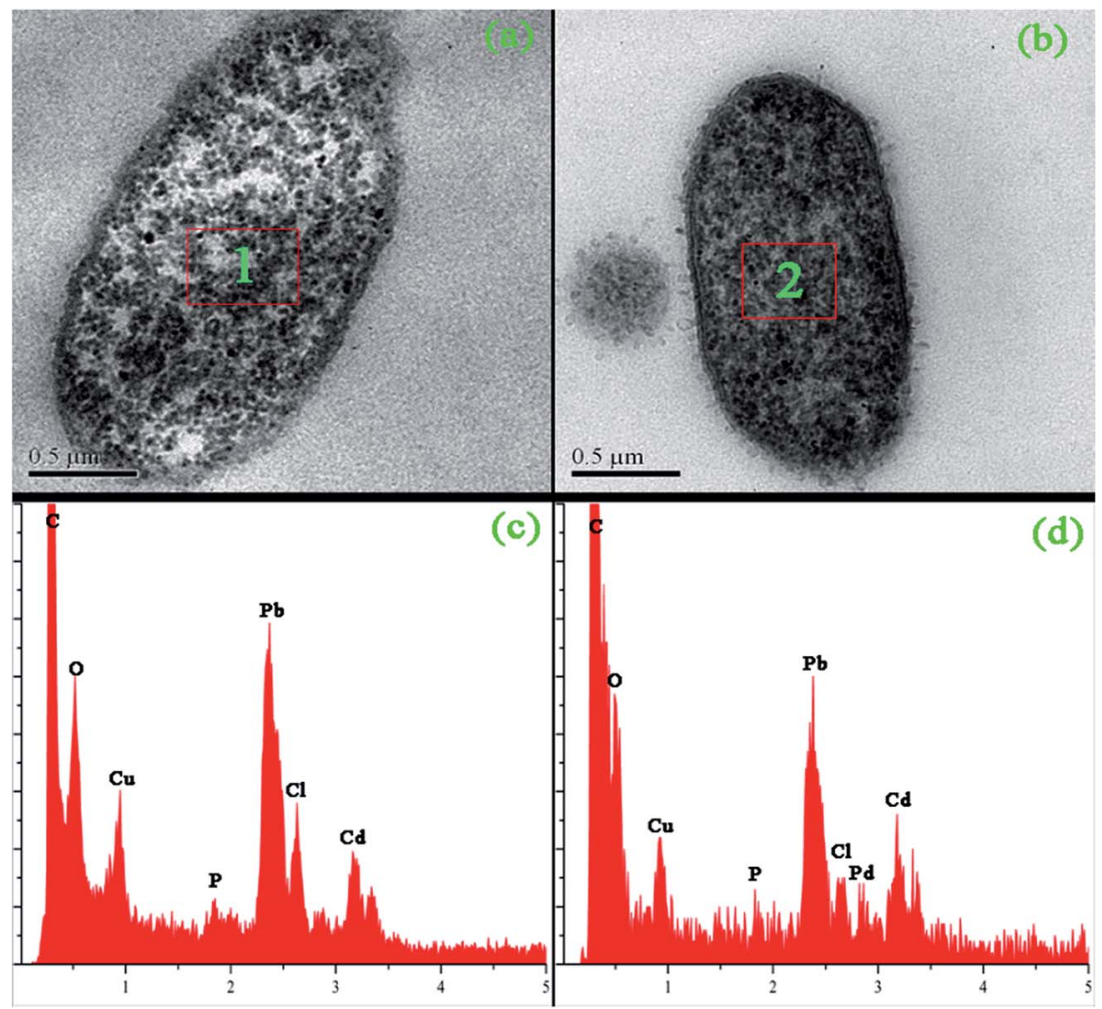

Fig. 5 TEM analyses of blank and palladium-loaded biomass after exposure to $200 \mathrm{mg} \mathrm{g}^{-1}$ aqueous PdCl ${ }_{2}$ solution for $3 \mathrm{~h}$. (a) TEM images of thin section of blank biomass; (b) TEM images of thin section of palladium-loaded biomass; (c) spot profile EDX spectrum recorded from region 1; (d) spot profile EDX spectrum recorded from region 2.

morphological change of palladium-loaded biomass was obvious, the change included the shape, adhesion and roughness properties. The palladium-loaded biomass became more roughened in the surface with the cell dimension changed (Fig. $6 \mathrm{c}$ and d). A great number of granules were appeared in the surface of palladium-loaded $P$. vermicola, and the boundaries between cells became ambiguous. Furthermore, unlike blank biomass that laid flat on the mica plate, the palladium-loaded biomass had a strong tendency toward formation of large clumps, which upon examination appeared to be both bacteria and nanoparticle aggregates coagulated together. This superficial change was attributed to the interactions between palladium ions and the surface of $P$. vermicola surface, the results were in accordance with the recent findings of Jiyeong Park ${ }^{2}$ and Stoimenov. ${ }^{38}$ In addition, the morphological changes of $\mathrm{Pb}^{2+}$ ion-exposed Bacillus cereus cells in the biosorption processes, including the size, shape and adhesive properties of the bacteria were also observed. ${ }^{39}$

\subsection{Functional groups characterization}

3.3.1 FTIR analysis. The cell walls of bacteria consist of several polymers and macromolecules, which have carboxyl, amide, hydroxyl and phosphate functional groups. From the FTIR adsorption peaks of $P$. vermicola biomass (Fig. 7), a number of absorption peaks and the complex nature of the biomass were examined and displayed. The adsorption range of $3200-3600 \mathrm{~cm}^{-1}$ represented $\mathrm{N}-\mathrm{H}$ asymmetric stretching of the amines and $\mathrm{O}-\mathrm{H}$ bond of the hydroxyl groups on the biomass surface. ${ }^{2,11,28}$ In this case, the intensity of peak valley at 3301 $\mathrm{cm}^{-1}$ in blank $P$. vermicola biomass was deepened and shifted after sorbing palladium, suggesting the $\mathrm{N}-\mathrm{H}$ and $\mathrm{O}-\mathrm{H}$ involvement to palladium adsorption. The absorption peaks at 1653 and $1541 \mathrm{~cm}^{-1}$ were attributed to the amide $\mathrm{I}(\mathrm{C}=\mathrm{O})$ and amide $\mathrm{II}(\mathrm{N}-\mathrm{H})$ bonds of the protein peptide bonds. ${ }^{2,35} \mathrm{~A}$ strong bond at $1455 \mathrm{~cm}^{-1}$ was characteristic of $-\mathrm{CH}_{2}$ scissoring motion and $-\mathrm{CH}_{3}$ antisymmetrical bending vibration, which were common in peptidoglycan, LPS, and phospholipids. ${ }^{40,41}$ The symmetric stretching of $\mathrm{COO}^{-}$vibration appeared around $1396 \mathrm{~cm}^{-1}, 2,35,42$ which had shifted to $1386 \mathrm{~cm}^{-1}$, demonstrated that carboxyl was a contributor in the sorption of $\operatorname{Pd}(\mathrm{II})$. Another strong bond around $1236 \mathrm{~cm}^{-1}$ was caused by functional groups, such as $\mathrm{P}=\mathrm{O}$ of polysaccharides and phospholipids inside the cell wall. ${ }^{41,43}$ The spectrum displayed adsorption peak at $1078 \mathrm{~cm}^{-1}$ moved to a lower frequency, which was related to the phosphate groups $\left(\mathrm{P}=\mathrm{O}\right.$ and $\mathrm{P}-\mathrm{O}$ of the $\mathrm{C}-\mathrm{PO}_{3}{ }^{2-}$ moiety) ${ }^{2,28,35}$ In contrast to the spectrum of blank biomass, the FTIR spectrum of palladium-loaded biomass showed that the peaks expected at $3301,1541,1396,1236$ and $1078 \mathrm{~cm}^{-1}$ had shifted to 3307,1538 , 1386, 1230, and 1068, respectively (Fig. 7). These shifts indicated that $\mathrm{N}-\mathrm{H}, \mathrm{O}-\mathrm{H},-\mathrm{COOH}, \mathrm{P}=\mathrm{O}$ and $\mathrm{P}-\mathrm{O}$, might be the predominant contributors in the sorption of $\mathrm{Pd}(\mathrm{II})$. On the other hand, since there was no big difference between the spectra of blank P. vermicola biomass and palladium-loaded biomass, especially for the main characteristic absorption peak (amide I 

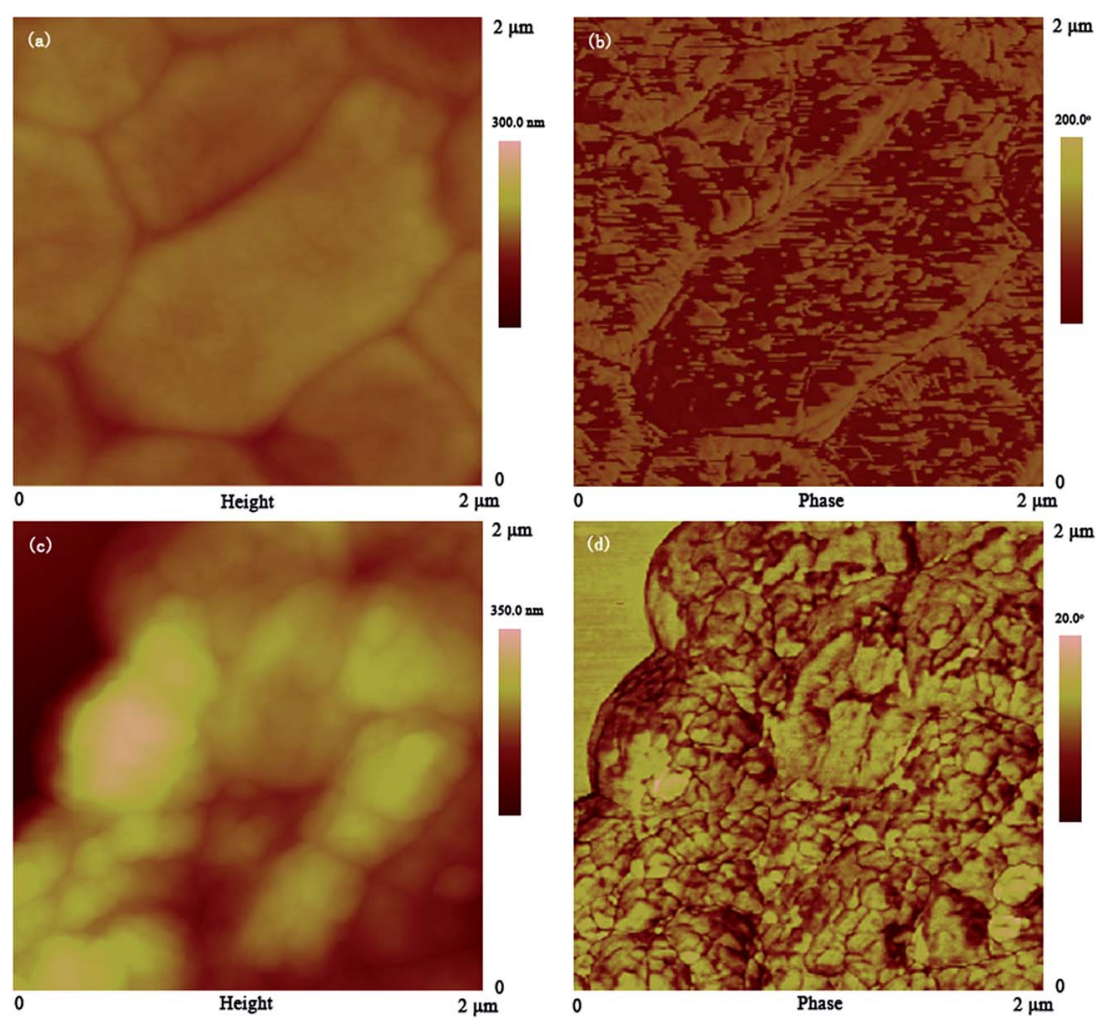

Fig. 6 AFM analyses of blank and palladium-loaded biomass after exposure to $200 \mathrm{mg} \mathrm{g}^{-1}$ aqueous PdCl 2 solution for $3 \mathrm{~h}$. (a) AFM height images of blank biomass; (b) AFM phase images of blank biomass; (c) AFM height images of palladium-loaded biomass; (d) AFM phase images of palladium-loaded biomass.

and amide II), indicating the structure and composition of $P$. vermicola was not destroyed after adsorbing palladium.

3.3.2 XPS analysis. The automatic environment changes before and after biosorption were characterized using XPS analysis. Fig. 8a showed that the wide scan spectrum comprised mainly carbon, nitrogen and oxygen. After palladium biosorption, a new peak corresponded to Pd 3d was clearly appeared. The Pd 3d signal of palladium-loaded biomass (Fig. 8b) was fitted to two pairs of doublets with a spin-orbit separation of $5.3 \mathrm{eV}$. It was reported that Pd $3 \mathrm{~d} 3 / 2(341.2 \mathrm{eV}), \mathrm{Pd}$ $3 \mathrm{~d} 5 / 2(335.9 \mathrm{eV})$ and Pd 3d3/2 (337.6 eV), Pd 3d5/2 (342.8 eV) could be assigned to $\mathrm{Pd}(0)$ and $\mathrm{Pd}(\mathrm{II})$, respectively. ${ }^{4-46}$ In this study, two signals (341.2 eV and $335.9 \mathrm{eV}$ ) corresponding to $\operatorname{Pd}(0)(3 \mathrm{~d} 3 / 2$ and $3 \mathrm{~d} 3 / 2)$ were detected, confirming the presence of elemental palladium. There were two possibilities that the elemental palladium stemmed from, first, Pd(II) anchored on the surface of $P$. vermicola was reduced to $\mathrm{Pd}(0)$; second, the $\operatorname{Pd}($ II) was reduced inside $P$. vermicola and released with the disruption of cells.

The $\mathrm{O} 1 \mathrm{~s}$ signal (Fig. 8c) in blank cells fitted to three different peaks (531.3, 532.3 and $533.1 \mathrm{eV}$ ), which could be attributed to carbonyl oxygen in amide and carboxyl, oxygen atoms in hydroxyls or ethers and oxygen atoms in esters, respectively. ${ }^{35} \mathrm{~A}$ minor shift of the peaks at 531.3 and $532.3 \mathrm{eV}$ to 531.4 and $532.4 \mathrm{eV}$ indicated the role of carboxyl and hydroxyl groups in palladium binding. This result was also consistent with the negative enthalpy $\left(\Delta H^{0}\right)$ in biosorption thermodynamics, which implied the $\mathrm{Pd}(\mathrm{II})$ might be bound to the oxygen atoms from active groups (e.g. $-\mathrm{COOH}$ and $-\mathrm{OH})$ on the cell wall.

Deconvolution of the $\mathrm{C} 1 \mathrm{~s}$ spectra (Fig. 8d) could generate four peaks at 284.5, 285.0, 286.1, and 287.9, which correspond to carbon making a single bond with carbon (C-C at $284.5 \mathrm{eV})$, carbon making a single bond with hydrogen $(\mathrm{C}-\mathrm{H}$ at $285.0 \mathrm{eV})$,

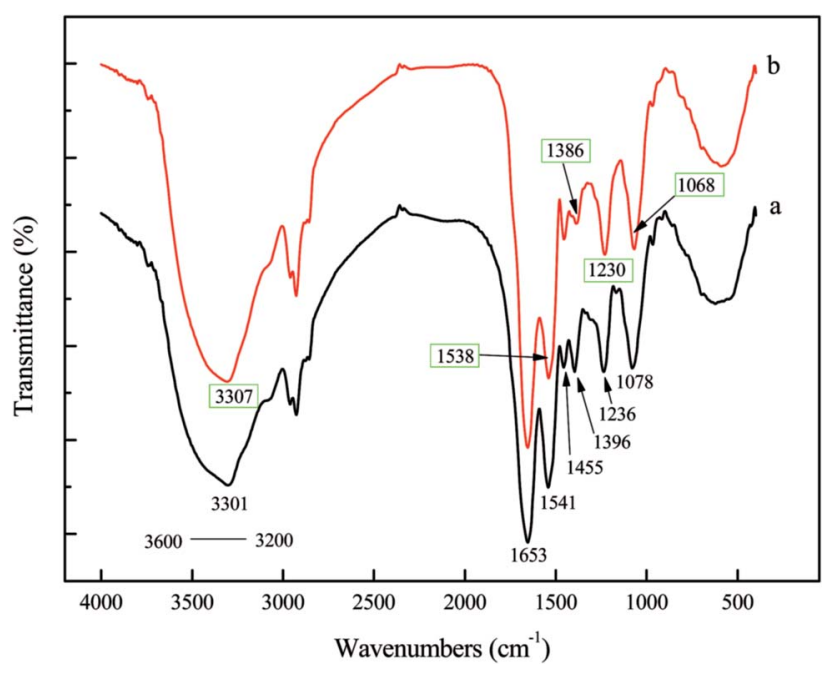

Fig. 7 FTIR spectrum of blank and palladium-loaded biomass after exposure to $200 \mathrm{mg} \mathrm{g}^{-1}$ aqueous $\mathrm{PdCl}_{2}$ solution for $3 \mathrm{~h}$. (a) Blank biomass; (b) palladium-loaded biomass. 

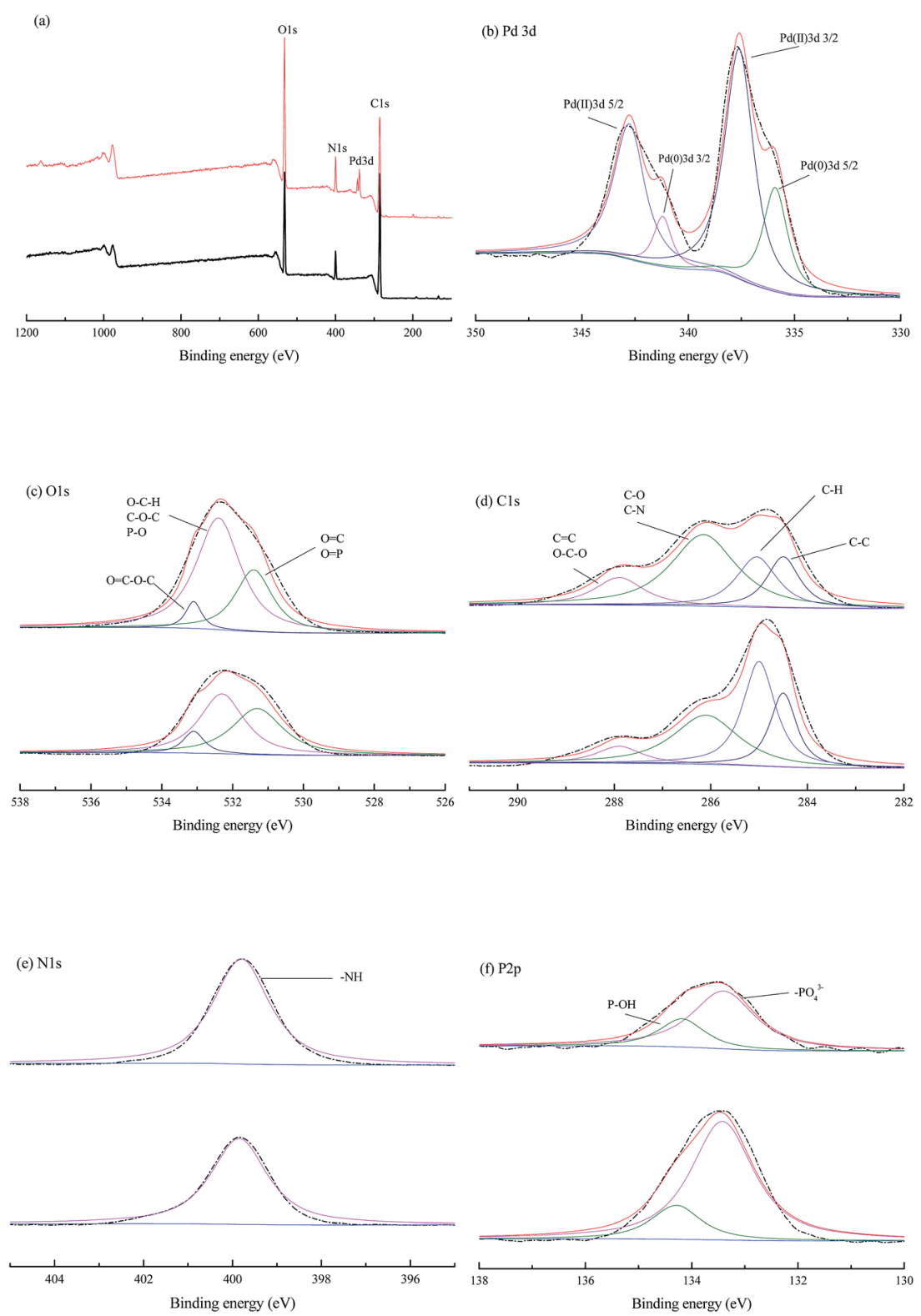

Fig. 8 X-ray photoelectron binding energy curves of blank (up) and palladium-loaded (down) biomass after exposure to $200 \mathrm{mg}^{-1}$ aqueous $\mathrm{PdCl}_{2}$ solution for 3 h. (a) Total survey scans; (b) Pd 3d spectra; (c) O 1s spectra; (d) C 1s spectra; (e) N 1s spectra; (f) P 2p spectra.

carbon bound to oxygen or nitrogen $(\mathrm{C}-\mathrm{O}, \mathrm{C}-\mathrm{N}$, at $286.1 \mathrm{eV}$, attributed to alcohol, amine or amide), carbon making two single bonds or one double bond with oxygen $(\mathrm{C}-\mathrm{O}-\mathrm{C}, \mathrm{C}=\mathrm{O}$ at 287.9, attributed to hemiacetal, acetal, amide and carboxylate) ${ }^{35,47}$ The carbon only bounded to carbon and hydrogen $\mathrm{C}-$ $(\mathrm{C}, \mathrm{H})$, might derive from lipids or the side chains of amino acids. Acetal or hemiacetal could arise from polysaccharides and sugar moieties. ${ }^{29}$ Further, the amide was expected to represent peptidic bonds, and carboxylate and carboxyl functional groups may be due to proteins and possibly uronic acids. $^{48}$

The XPS spectrum (Fig. 8e) showed a single $\mathrm{N}$ 1s peak at $399.8 \mathrm{eV}$ in both blank and palladium-loaded $P$. vermicola, attributable to nitrogen in $-\mathrm{NH}_{2}$ groups, ${ }^{2,11}$ which implied a single chemical environment in $P$. vermicola. The fitted $\mathrm{P} 2 \mathrm{p}$ envelope (Fig. 8f) indicated the presence of two components, positions of 133.3 and $134.2 \mathrm{eV}$, which corresponded to the $\mathrm{P}$ 2p3/2 and P 2p1/2 states of phosphorus in P. vermicola. The P 2p peak locating at $133.3 \mathrm{eV}$ could be deconvoluted into contributions from the $\mathrm{P}(\mathrm{v})$ oxidation state, corresponding to the $-\left[\mathrm{PO}_{4}\right]^{3-}$, while $134.2 \mathrm{eV}$ corresponding to $\mathrm{P}-\mathrm{OH} .^{49,50}$

In summary, both $\operatorname{Pd}(0)$ and $\operatorname{Pd}(\mathrm{II})$ were detected on the surface of $P$. vermicola biomass, and $\mathrm{O}$ atom was related to the biosorption of palladium ions. The peaks of $\mathrm{C}, \mathrm{N}, \mathrm{P}$ between blank and palladium-loaded $P$. vermicola remained unchanged, but the peak area ratio of binding energy peaks was different, which implied the possible sorption capabilities of those atoms. When comes to the biosorption of uranium by a novel 
Streptomyces sporoverrucosus dwc-3, the XPS and FT-IR analysis suggested that the absorbed uranium was bound to amino, phosphate and carboxyl groups of the cells. ${ }^{35}$

\subsection{Functional groups confirmation}

3.4.1 Chemical modification of $P$. vermicola biomass. The effects of chemical treatment on the functional groups could be evaluated from the differences among the spectrums. The curve in Fig. 9b portrayed the FTIR spectrum of $P$. vermicola treated with methanol and hydrochloric acid, which resulted in the esterification of carboxyl groups. When comparing Fig. 9a with $\mathrm{b}$, the carboxyl related peaks at wave number of $1653 \mathrm{~cm}^{-1}$ and $1396 \mathrm{~cm}^{-1}$ in blank biomass (Fig. 9a), which represented $\mathrm{C}=\mathrm{O}$ in amide $\mathrm{I}$ and $\mathrm{COO}^{-}$respectively, changed significantly. Specifically, the former shifted to $1646 \mathrm{~cm}^{-1}$, and the trough observed at $1396 \mathrm{~cm}^{-1}$ almost disappeared. In addition, the methanol-treated biomass clearly displayed shifts of $\mathrm{O}-\mathrm{H}$ bond located at $3301 \mathrm{~cm}^{-1}$ because the addition of extra $-\mathrm{OH}$ in methanol.
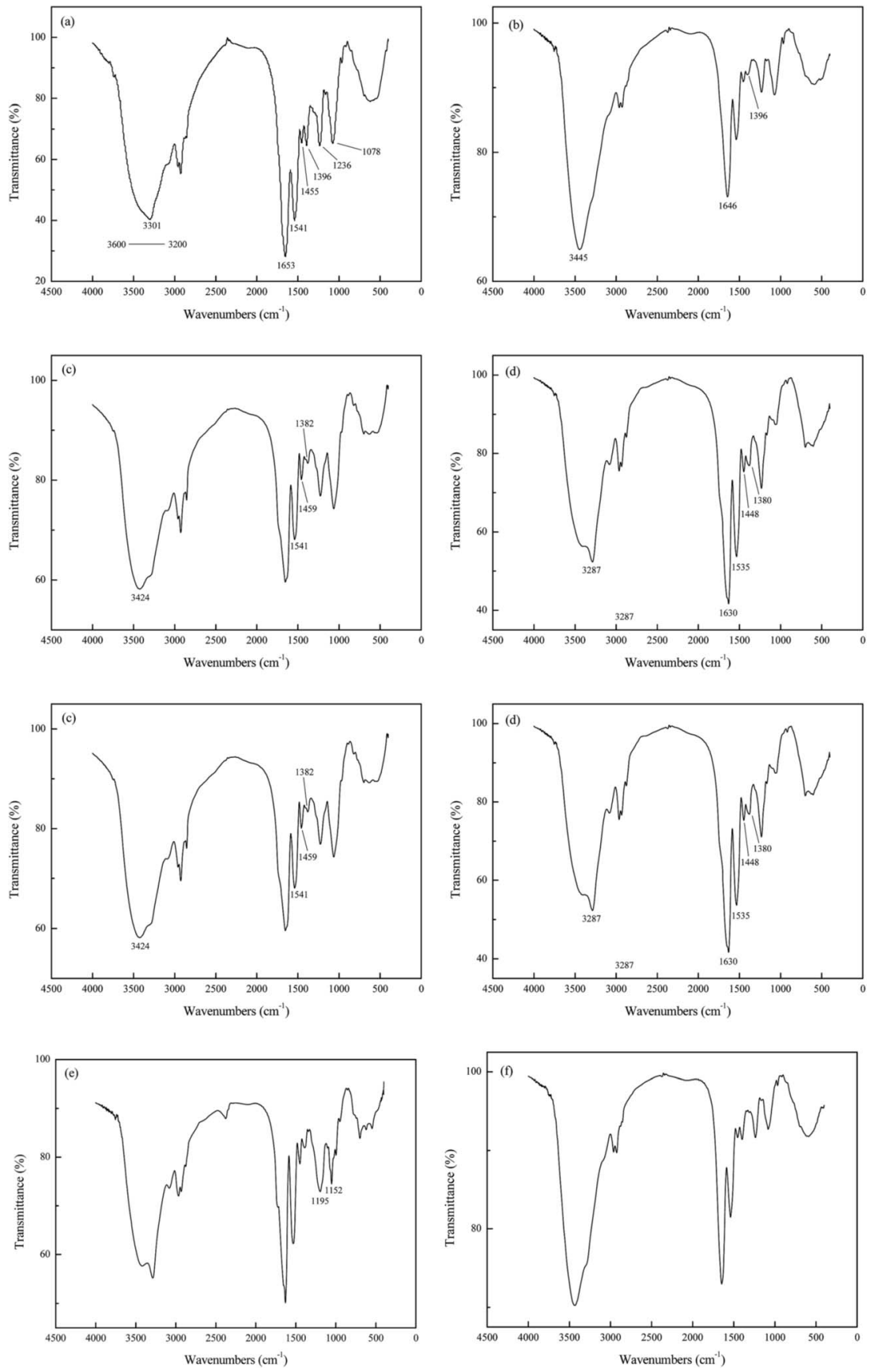

Fig. 9 FTIR spectra of blank and chemically modified biomass. (a) Blank biomass, (b) biomass treated with methanol and hydrochloric acid, (c) biomass treated with formic acid and formaldehyde, (d) biomass treated with acetic anhydride and pyridine, (e) biomass treated with triethyl phosphite and nitromethane, (f) biomass treated with acetone. 
Treatment of biomass with formic acid and formaldehyde gave rise to the methylation of amino groups as depicted in Fig. 9c. The peak at $3301 \mathrm{~cm}^{-1}$ (N-H and $\mathrm{O}-\mathrm{H}$ bond) shifted to $3424 \mathrm{~cm}^{-1}$, which suggested certain changes had been happened to the amino groups presented in the biomass. The $\mathrm{N}-\mathrm{H}$ bond at wave of $1541 \mathrm{~cm}^{-1}$ remained the same, indicating the major components and structure of biomass remained intact. On the other hand, the peak at $1396 \mathrm{~cm}^{-1}$ represented $\mathrm{COO}^{-}$shifted to $1382 \mathrm{~cm}^{-1}$, implying the modification not only changed the amide groups on the biomass but also the carboxyl groups. Furthermore, a change in the peak $1455 \mathrm{~cm}^{-1}$ in the spectrum of the treated sample confirmed the change in methyl as reaction (3) showed.

The Fig. 9d shows the FTIR spectrum of biomass treated with acetic anhydride and pyridine which could esterify the hydroxyl groups and the amines simultaneously. The hydroxyl and amine peaks at $3301 \mathrm{~cm}^{-1}$ represented $\mathrm{N}-\mathrm{H}$ asymmetric stretching of the amines and $\mathrm{O}-\mathrm{H}$ bond of the hydroxyl groups, and 1541 $\mathrm{cm}^{-1}$ represented $\mathrm{N}-\mathrm{H}$ bonds in amide II. Those two peaks shifted to $3287 \mathrm{~cm}^{-1}$ and $1535 \mathrm{~cm}^{-1}$ respectively, verifying the modification of function group in biomass. Likewise, the peaks at $1653 \mathrm{~cm}^{-1}, 1455 \mathrm{~cm}^{-1}$ and $1396 \mathrm{~cm}^{-1}$ moved to $1630 \mathrm{~cm}^{-1}$, $1448 \mathrm{~cm}^{-1}$ and $1380 \mathrm{~cm}^{-1}$ respectively, which might due to the residual acetic anhydride and formation of amino and acetic acid as reaction (4) showed.

The Fig. 9e displayed the FTIR spectrum of biomass treated with triethyl phosphite and nitromethane which could esterify the phosphate groups. The peaks at wave number of $1236 \mathrm{~cm}^{-1}$ and $1078 \mathrm{~cm}^{-1}$ moved to $1195 \mathrm{~cm}^{-1}$ and $1052 \mathrm{~cm}^{-1}$ with a very different spectral intensity in this chemically modified biomass.

As shown in Fig. 9f, the wave numbers of peaks in biomass treated with acetone remained a relative unchanged positions, which indicated the extraction of lipid fraction did not affect the structure and function groups of $P$. vermicola.

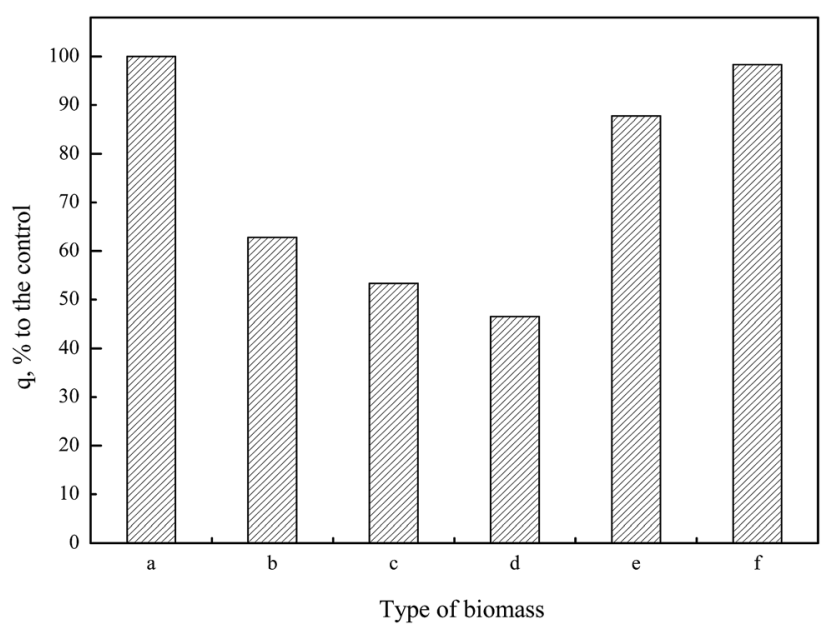

Fig. 10 Palladium biosorption efficiency of blank and chemically modified biomass. (a) Blank biomass, (b) biomass treated with methanol and hydrochloric acid, (c) biomass treated with formic acid and formaldehyde, (d) biomass treated with acetic anhydride and pyridine, (e) biomass treated with triethyl phosphite and nitromethane, (f) biomass treated with acetone.
In summary, Fig. 9 showed a strong evidence of successful chemical modification on blank P. vermicola. Those modified biomass could be used to verify the effects of carboxyl, amine, hydroxyl, phosphate and lipid groups on the surface of cell wall.

3.4.2 Experimental confirmation of functional groups. The modification of those function groups definitely affected the capacity of $P$. vermicola biomass. Results of metal binding studies for blank and chemically treated $P$. vermicola biomass were shown in Fig. 10. Biosorption of palladium was observed to be severely inhibited (about $40 \%$ reduction of uptake) when carboxylic groups was esterified (b), indicating the important role of carboxylic groups in the biosorption of Pd(II). Since the formaldehyde used for methylation of amines could also replace the $\mathrm{H}$ atoms present on $\mathrm{COOH}$, the effect of the formic acid-formaldehyde treatment (c) would indicate the contribution of amino and carboxyl groups. ${ }^{14}$ By combining the results from treatments b and c, it could be concluded that Pd(II) biosorption was more sensitive to the modifications of the carboxyl groups than that of the amine groups, where the observed reduction of the uptake was found to be about $40 \%$ and $10 \%$ respectively. The reduction of the uptake caused by modification of hydroxyl and amine groups (d) was about $50 \%$. By eliminating the contribution of amine groups (about 10\%), the contribution of hydroxyl groups in biosorption was about $40 \%$, which played a comparable role as carboxylic groups. More than $10 \%$ decrease in the palladium uptake was observed in sample treated with nitromethane and triethyl phosphite (e), suggesting phosphate groups represented the fraction of reactive groups in the surface of $P$. vermicola. It was expected that extraction of the lipid fraction might alter the uptake level of palladium. However, the results (f) treatment exhibited a very slight decrease (about $2 \%$ ) in adsorption capacity, implying that any biomass constituents extracted in these treatments did not contribute to the uptake of palladium.

In Pd(II) biosorption, the spectral analysis and biosorption test disclosed that the most efficient functional group on the cell wall of $P$. vermicola were carboxylic and hydroxyl groups which was followed by phosphate and amine groups. The effect of chemical modification on metal uptake capacity appeared to be biomass-dependent. As for Saccharomyces cerevisiae, although a reduction of $53.38 \%$ in lead biosorption was recorded due to methylation of amine groups, the drastic reduction by $96.34 \%$ when carboxylic acids was esterified, revealed that the carboxylic group contributed most significantly to lead biosorption. ${ }^{51}$ Another research demonstrated that both modification of carboxylic and amine groups on the cell wall of Saccharomyces cerevisiae resulted in the decrease of biosorption capacity, but copper biosorption was more sensitive to modifications of the amine groups than of the carboxyl group..$^{52}$ On the other hand, Kılıç et al. ${ }^{15}$ reported that carboxylic acids were more effective in $\mathrm{Pb}$ (II) sequestration while amine groups turned out to be more effective in $\mathrm{Hg}$ (II) sequestration. Seki et $a l .{ }^{53}$ showed that the interactions between the imidazol groups and the metal anions were relatively strong; however, the interactions between the amino groups and $\mathrm{As}(\mathrm{v})$ anions were very weak. Furthermore, Hydroxyl groups in the surface of Penicillium cyclopium were identified as providing the major 
sites of heavy metal deposition, followed by amides and carboxylates. Phosphate groups and the lipids fraction of the biomass did not play significant role in biosorption of the metal ions in the studied biomass. ${ }^{16}$ Carboxylate, amine and phosphate groups played an important role in the biosorption of metal ions by Mucor rouxii biomass. ${ }^{9}$

\section{Conclusions}

Results in this study showed the exact palladium uptake process, multi-scale visualization of palladium-loaded biomass and confirmed the contribution of functional groups to $\operatorname{Pd}(\mathrm{II})$ biosorption by $P$. vermicola biomass could be used as potential biosorbent for the recovery of $\mathrm{Pd}(\mathrm{II})$ from aqueous solutions (with an uptake of $115.79 \mathrm{mg} \mathrm{g}^{-1}$ under condition of $\mathrm{pH} 4$, initial Pd(II) $200 \mathrm{mg} \mathrm{L}^{-1}, 30^{\circ} \mathrm{C}$ ). The pseudo-first order, pseudosecond order and intraparticle diffusion model indicated that chemical reaction was significant in the rate-controlling step and two steps governed adsorption rather than one. For equilibrium isotherms, Langmuir model fitted the $\operatorname{Pd}($ II) adsorption data better than the Freundlich model, implying a monolayer adsorption trend. During the biosorption of palladium ions onto $P$. vermicola, the process is spontaneous and endothermic, and the randomness at the solid/liquid interface increases. SEM-EDX and TEM-EDX analyses identified that palladium ions were sorbed into both the external and internal of $P$. vermicola biomass, and the wt\% of $\mathrm{Pd}$ and $\mathrm{Cl}$ in the surface of biomass reached $18.40 \%$ and $4.32 \%$, respectively. As it was showed in AFM images, the morphologic properties of the palladiumloaded biomass changed considerably in the nanometer range. After sorbing $\operatorname{Pd}(\mathrm{II})$, P. vermicola biomass and nanoparticle aggregates coagulated together to form large clumps, which could attributed to the interactions between palladium ions and the surface of $P$. vermicola surface. In addition, the FTIR analysis indicated the involvement of $\mathrm{N}-\mathrm{H}, \mathrm{O}-\mathrm{H},-\mathrm{COOH}$, $\mathrm{P}=\mathrm{O}$ and $\mathrm{P}-\mathrm{O}$ in the sorption of $\mathrm{Pd}(\mathrm{II})$. The sorbed palladium ions were of zero-valent and divalent forms, and $\mathrm{O}, \mathrm{C}, \mathrm{N}$ and $\mathrm{P}$ atoms might possess sorption capabilities. By chemical modification, the spectral analysis and biosorption test disclosed that the decreasing contribution order of different functional groups in $P$. vermicola surface was carboxylic groups, hydroxyl groups, phosphate groups and amine groups, which caused about $40 \%, 40 \%, 10 \%$ and $10 \%$ reduction of palladium uptake. Future studies should focus on the industrial application of $P$. vermicola biomass by increasing the functional groups of surface through chemical or biological modification.

\section{Acknowledgements}

This work was supported by the China Postdoctoral Science Foundation (2015T80880), the National Natural Science Foundation of China (51104189), the $53^{\text {rd }}$ China Postdoctoral Science Foundation (2013M531814), and the State Key Laboratory of Advanced Technologies for Comprehensive Utilization of Platinum Metals (SKL-SPM-201508).

\section{References}

1 M. D. Yates, R. D. Cusick and B. E. Logan, ACS Sustainable Chem. Eng., 2013, 1, 1165-1171.

2 J. Park, S. W. Won, J. Mao, I. S. Kwak and Y. S. Yun, J. Hazard. Mater., 2010, 181, 794-800.

3 Q. Yi, R. Fan, F. Xie, Q. Zhang and Z. Luo, J. Taiwan Inst. Chem. Eng., 2016, 61, 299-305.

4 S. Morisada, Y. H. Kim, T. Ogata, Y. Marutani and Y. Nakano, Ind. Eng. Chem. Res., 2011, 50, 1875-1880.

5 S. W. Won, A. Lim and Y. S. Yun, Bioresour. Technol., 2013, 137, 400-403.

6 L. Le, H. Nan, D. Dexin, X. Xin, W. Yongdong, X. Jinhua, Z. Hui and T. Yan, RSC Adv., 2015, 5, 65827-65839.

7 I. Michalak, K. Chojnacka and A. Witek-Krowiak, Appl. Biochem. Biotechnol., 2013, 170, 1389-1416.

8 E. A. Dil, M. Ghaedi, G. R. Ghezelbash, A. Asfaram, A. M. Ghaedi and F. Mehrabi, $R S C A d v$., 2016, 6, 5414954161.

9 G. Yan and T. Viraraghavan, Eng. Life Sci., 2008, 8, 363-371. 10 K. Chojnacka, A. Chojnacki and H. Gorecka, Chemosphere, 2005, 59, 75-84.

11 S. W. Won, J. Mao, I. S. Kwak, M. Sathishkumar and Y. S. Yun, Bioresour. Technol., 2010, 101, 1135-1140.

12 A. E. Abo-Amer, A. B. Ramadan, M. Abo-State, M. A. AbuGharbia and H. E. Ahmed, J. Basic Microbiol., 2013, 53, 477-488.

13 S. Omeike, S. Kareem, S. Adewuyi and S. Balogun, J. Life Sci., 2013, 15, 119-124.

14 A. Kapoor and T. Viraraghavan, Bioresour. Technol., 1997, 61, 221-227.

15 M. Kılıç, M. E. Keskin, S. Mazlum and N. Mazlum, Int. J. Miner. Process., 2008, 87, 1-8.

16 K. Tsekova, D. Christova and M. Ianis, Journal of Applied Sciences and Environmental Management, 2006, 10, 117-121.

17 J. Tobin, D. Cooper and R. Neufeld, Enzyme Microb. Technol., 1990, 12, 591-595.

18 J. Febrianto, A. N. Kosasih, J. Sunarso, Y. H. Ju, N. Indraswati and S. Ismadji, J. Hazard. Mater., 2009, 162, 616-645.

19 Y. S. Ho and G. McKay, Process Biochem., 1999, 34, 451-465.

20 W. J. Weber and J. C. Morris, J. Sanit. Eng. Div., Am. Soc. Civ. Eng., 1963, 89, 31-60.

21 A. E. Ofomaja, Bioresour. Technol., 2010, 101, 5868-5876.

22 M. Gan, S. Sun, Z. Zheng, H. Tang, J. Sheng, J. Zhu and X. Liu, Appl. Surf. Sci., 2015, 356, 986-997.

23 M. Gan, Z. Zheng, S. Sun, J. Zhu and X. Liu, RSC Adv., 2015, 5, 94500-94512.

24 A. E. Ofomaja, Chem. Eng. J., 2008, 143, 85-95.

25 Y. S. Ho and A. E. Ofomaja, Biochem. Eng. J., 2006, 30, 117123.

26 M. Jain, V. Garg, U. Garg, K. Kadirvelu and M. Sillanpaa, Int. J. Environ. Res., 2015, 9, 1079-1088.

27 A. Sari, D. Mendil, M. Tuzen and M. Soylak, J. Hazard. Mater., 2009, 162, 874-879.

28 S. Kim, M. H. Song, W. Wei and Y. S. Yun, J. Hazard. Mater., 2015, 283, 657-662. 
29 Z. Lin, J. Wu, R. Xue and Y. Yang, Spectrochim. Acta, Part A, 2005, 61, 761-765.

30 J. Gardea-Torresdey, K. Tiemann, V. Armendariz, L. BessOberto, R. Chianelli, J. Rios, J. Parsons and G. Gamez, J. Hazard. Mater., 2000, 80, 175-188.

31 M. Ghaedi, S. Hajati, F. Karimi, B. Barazesh and G. Ghezelbash, J. Ind. Eng. Chem., 2013, 19, 987-992.

32 H. Xie, Q. Zhao, Z. Zhou, Y. Wu, H. Wang and H. Xu, RSC Adv., 2015, 5, 33478-33488.

33 L. Ramrakhiani, R. Majumder and S. Khowala, Chem. Eng. J., 2011, 171, 1060-1068.

34 S. Srivastava and I. S. Thakur, Curr. Microbiol., 2006, 53, 232237.

35 X. Li, C. Ding, J. Liao, L. Du, Q. Sun, J. Yang, Y. Yang, D. Zhang, J. Tang and N. Liu, J. Environ. Sci., 2016, 41, 162-171.

36 J. B. Omajali, I. P. Mikheenko, M. L. Merroun, J. Wood and L. E. Macaskie, J. Nanopart. Res., 2015, 17, 1-17.

37 K. Tamaoki, N. Saito, T. Nomura and Y. Konishi, Hydrometallurgy, 2013, 139, 26-29.

38 P. K. Stoimenov, R. L. Klinger, G. L. Marchin and K. J. Klabunde, Langmuir, 2002, 18, 6679-6686.

39 J. Pan, X. Ge, R. Liu and H. Tang, Colloids Surf., B, 2006, 52, 89-95.

40 J. Bai, H. Yao, F. Fan, M. Lin, L. Zhang, H. Ding, F. Lei, X. Wu, X. Li and J. Guo, J. Environ. Radioact., 2010, 101, 969-973.
41 J. Jena, N. Pradhan, B. Dash, L. Sukla and P. Panda, Int. J. Nanomater. Biostruct., 2013, 3, 1-8.

42 Y. Yin, Y. Hu and F. Xiong, Int. Biodeterior. Biodegrad., 2011, 65, 1012-1018.

43 H. P. Song, X. G. Li, J. S. Sun, S. M. Xu and X. Han, Chemosphere, 2008, 72, 616-621.

44 J. Wan, R. Ran, X. Wu, Y. Cao, M. Li, D. Weng and K. Huang, Catal. Today, 2015, 253, 51-56.

45 S. Yang, J. Dong, Z. Yao, C. Shen, X. Shi, Y. Tian, S. Lin and X. Zhang, Sci. Rep., 2014, 4, 1-6.

46 J. Zhang, Y. Xu and B. Zhang, Chem. Commun., 2014, 50, 13451-13453.

47 H. Bubert, W. Brandl, S. Kittel, G. Marginean and D. Toma, Anal. Bioanal. Chem., 2002, 374, 1237-1241.

48 F. Ahimou, C. J. Boonaert, Y. Adriaensen, P. Jacques, P. Thonart, M. Paquot and P. G. Rouxhet, J. Colloid Interface Sci., 2007, 309, 49-55.

49 Y. Shen, T. Xiong, H. Du, H. Jin, J. Shang and K. Yang, J. SolGel Sci. Technol., 2009, 50, 98-102.

50 W. Gao, B. Feng, Y. Ni, Y. Yang, X. Lu and J. Weng, Appl. Surf. Sci., 2010, 257, 538-546.

51 K. Parvathi, R. Nagendran and R. Nareshkumar, Electron. J. Biotechnol., 2007, 10, 92-105.

52 W. Jianlong, Process Biochem., 2002, 37, 847-850.

53 H. Seki, A. Suzuki and H. Maruyama, J. Colloid Interface Sci., 2005, 281, 261-266. 